\title{
SOCIAL RESPONSIBILITY IN HIGH EDUCATION INSTITUTIONS: EVIDENCE FROM ECONOMIC FACULTIES IN CZECH REPUBLIC
}

\author{
Renata Kučerová $^{1 凶}$, Sylvie Formánková2 Monika Prísažná $^{3}$ \\ ${ }^{1 \bowtie}$ Departement of Management, Faculty of Business and Economics, MENDELU in Brno, Zemědelská 1, Brno, 613 00, Czech Republic, \\ +420545132501, renata.kucerova@mendelu.cz \\ ${ }^{2}$ Departement of Management, Faculty of Business and Economics, MENDELU in Brno, Czech Republic \\ ${ }^{3}$ Departement of Management, Faculty of Business and Economics, MENDELU in Brno, Czech Republic
}

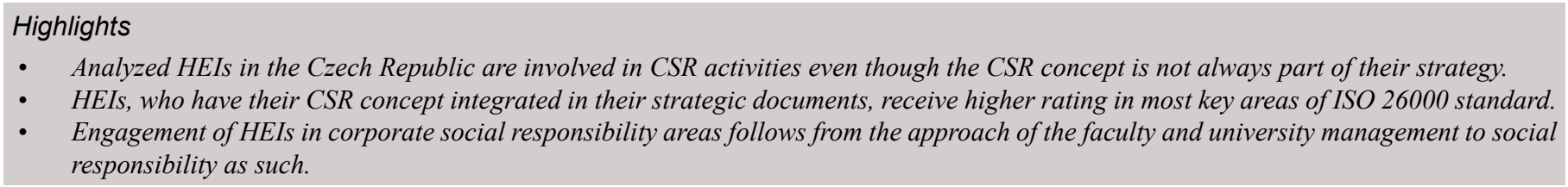

\section{Abstract}

The presented paper shows results of a qualitative survey of corporate social responsibility (CSR) in the

Article type tertiary education sector. Economically oriented faculties of public universities in the Czech Republic were selected. For the assessment of High Education Institutions' engagement in CSR activities seven key areas covered by ISO 26000 standard were used. Analyzed High Education Institutions in the Czech Republic are engaged in many CSR activities but these activities are often untargeted and representing by-products of other activities. The main drawbacks of all assessed faculties in the key area five "Environment" were discovered The results for the first key area - "Organisational governance" show of their overall engagement in corporate socially responsible activities.

\section{Keywords}

Economic faculty, engagement, ISO 26000 , public university, social responsibility, strategy

Kučerová R., Formánková S., Prísažná M. (2016) "Social Responsibility in High Education Instituions: Evidence from Economic Faculties in Czech Republic", Journal on Efficiency and Responsibility in Education and Science, Vol. 9, No. 4, pp. 88-96, online ISSN 1803-1617, printed ISSN 2336-2375, doi: 10.7160/eriesj.2016.090401.

\section{Introduction}

Corporate social responsibility (CSR) has become a common and significant part of business in many countries. CSR brings a competitive edge to the businesses in the form of higher motivation of employees as stated for example by Milton de Sousa Filho et al. (2010), also improving image, reputation, and improving customer loyalty (Aya Pastrana and Sriramesh, 2014). According to Flammer (2013), CSR can bring better access of the business to finance, predicts innovation climate in the firm (Ubius and Alas, 2012) and have a positive impact on the whole business performance (Yusoff, Mohamad and Darus, 2013).

The huge boom of the CSR concept in the profit sector increases importance of CSR teaching. Future managers need to be equipped with competences for introduction and management of the corporate social responsibility concept. According to Vazquez, Lanero, Licandro (2013), the prioritised introduction of CSR teaching is currently supported by three reasons. The first reason is the CSR concept development in the world of business, increasing the demand for professionals qualified for responsible governance. The second reason is that CSR has been increasingly popular also outside the private sphere. CSR has been a frequently discussed theme at governmental meetings, supra-national organisations, social organisations and other institutions. This sense, the idea that sustainable development largely depends on the responsible behaviour of both organizations and citizens is more and more consolidated. And thirdly, all of this have led universities to ask themselves about their own responsibility thus gaining awareness of their role in the education and training of professionals provided with the competences and values needed for sustainable development.
Universities are well aware of the need of education in this very area. Many business schools worldwide have consequently integrated CSR and sustainability-related topics into their management programmes (Moratis, 2014). As shown by Giacalone and Thompson (2006), very important is how students will be educated in the area of business ethics and corporate social responsibility. The need of established ethical frameworks and procedures in business circles has never been bigger (Jorge and Peña, 2014). This is also documented by research results of Ahmad (2012) who says that students must be well-informed and exposed to the benefits of CSR initiatives and then their levels of participation in CSR activities is high. The universities are still superior at satisfying public demand for quality education (Othman and Othman, 2014) and provide students with the maximum breadth and depth of the theoretical knowledge (Stojanová and Tomšík, 2014).

Corporate social responsibility teaching is however only one side of the coin. Universities themselves should be an example for their students and for businesses, behave responsibly and include the CSR concept in their activities. In addition, corporate social responsibility can become a competitive advantage for the university or higher educational institution itself. Involvement of universities in CSR activities is however a new and still developing phenomenon. The concept of CSR and its principles are yet to be proven in the higher education industry (Othman and Othman, 2014).

This is also closely connected to the role of universities. The educational and research role has recently been extended with the social role. While some universities and higher education 
institutions only understand this role as a link to the business sphere and business supporting activities, others take it as an active social role very closely connected with socially responsible behaviour to all their stakeholders. Yokoyama (2006) speaks about business university performing activities such as establishment of businesses, advisory activities, community service and scholarship provision.

Lehmann et al (2009), on the other hand, emphasizes the fact that universities are here to develop human and intellectual capital, produce simultaneous effect on the natural and production capital as well as institutional capital of the society and are to be involved in network, cooperation and trust building in the society which is becoming more and more dependent on these values.

This paper includes an analysis of involvement of the High Education Institutions (HEIs) - three faculties of economics of public universities in the Czech Republic - in corporate social responsibility activities. The main prerequisite is making CSR part of strategic management of the university without which CSR development at the university can never be sufficient.

Partial results of the research were presented at the 6th International Conference on Management - ICOM 2016 (Formánková, Kučerová, Prísažná, 2016). Paper from this conference includes the analysis and the results of only one faculty and its participation in the social responsibility concept. This paper is the extended version and contains an analysis of three economic faculties of public universities, comparison of results and their approach and application of CSR principles in their activities, conclusions and recommendations resulting from this comparison.

The research efforts are to bring the knowledge of the current situation in the area of social responsibility of universities and thereby contribute to its development.

The paper is divided into three sections - the results of faculties' engagement in CSR activities; their comparison; and discussion of findings in relation to behaviour of each faculty in the assessed areas.

\section{Materials and Methods}

The subjects of the present research have been faculties of economics of three public universities of the Czech Republic - the Faculty of Business and Economics (FBE), Mendel University in Brno, the Faculty of Economics and Administration (FEA), Masaryk University in Brno, and the Faculty of Business and Management (FBM), Brno University of Technology.

The research was conceived as qualitative and performed through controlled interviews with competent representatives of the faculties and management of the universities. The controlled interviews followed from a questionnaire pursuant to the international ISO 26000 (ISO, 2013) standard, adapted for public universities with economic orientation. There were 7 key evaluated areas and further sub-areas pursuant to the applied standard (ISO, 2013):

6.2 Organizational governance - Accountability, transparency, ethical conduct, consideration of stakeholders' interests and legal compliance (KO-1)

6.3 Human rights $(\mathrm{KO}-2)$
6.4 Labour practices (KO-3)

6.5 Environment (KO-4)

6.6 Governance based on rules - fair operating practices (KO-5)

6.7 Consumer issues (KO-6)

6.8 Community involvement and development (KO-7)

The controlled interviews were primarily focused on corporate social responsibility of the evaluated faculties in their approach to students, employees, the community, the environment and interest groups. The approach was assessed with regard of involvement of the individual faculties in CSR activities as well as CSR teaching.

As some CSR activities are performed and managed on the university level faculty activities could not always be clearly distinguished from university activities in the CSR area. Where the faculties were involved in or affected by university-wide CSR activities there these activities were included in the assessment.

The results obtained from the controlled interviews were combined with information from strategic documents of the assessed faculties and from other resources. These included long-term projects of the faculties and the universities for the period 2016-2020, and their updated versions for 2016, rectors' decrees and guidelines, disciplinary rules and annual reports on faculty and university activities and data and reports published in the faculty and university web sites, faculty articles of association, ethical codes and other documents.

The qualitative research results were assessed by the methodology used for analysis of socially responsible conduct at the Pedagogical Faculty of Catholic University at Ružomberk using ISO 26000 standard (Madzík, P. et al., 2015). The methodology fully respects the main principles and recommendations of the standard. ISO 26000 standard is only recommending and selfevaluating in nature using perception and evaluation of the project teams.

Quantification and assessment of faculty activities in the individual key areas uses numerical scale from 1 to $3(1,2,3)$. The scale is based on a similar method by Černohorská and Putnová (2012). For simplification the scale was modified from 5 to 3 points, where $1=$ MIN and $3=$ MAX, meaning:

- 1 - Involvement of the faculty in the given activity is negligible and its corporate social responsibility is minimal,

- 2 - Involvement of the faculty in the given activities is small to medium and its corporate social responsibility is average,

- $\quad 3$ - The activity is significant for the faculty, paid much attention to and therefore the faculty corporate socially responsible engagement is maximal.

The resulting assessment of involvement of the evaluated faculties in the individual key areas is calculated as the ratio of the total intensity of the individual key areas (KO-1 - KO-7) and the total number of sub-areas within every key area.

The present paper shows particular results obtained by controlled interviews with competent representatives of the individual assessed faculties in the individual key areas of KO $1-\mathrm{KO} 7$ in comparison of the individual faculties with regard to their CSR involvement. 


\section{Results}

\section{Faculty of Business and Economics (FBE), Mendel University in Brno}

Key area KO-1 - Organizational governance

FBE achieved the score of 1.88 (see Table 1). FBE currently does not have CSR principles incorporated in the faculty strategy and management - they are no part of the long-term strategy for 2016-2020, i.e. there is not CSR strategy at FBE yet. The management of FBE does not yet consider corporate social responsibility substantially beneficial for the faculty. FBE does not create CSR report and has not implemented special CSR standards in its activities. However, even though the conduct of FBE is not targeted, the faculty subconsciously does many socially responsible activities. FBE complies with principles of ethical conduct and tries to consider stakeholders' interests. FBE complies with the law of the Czech Republic.

\section{Key area $\mathrm{KO}-2$ - Human rights}

FBE rating is above-average (2.26 - see Table 1). However, activities in this area pursuant to ISO 26000 standard closely correspond to compliance with Czech law in the human rights area. Hence such a high rating. FBE principally does not engage in activities outside the scope of its legal commitments.

\section{Key area KO-3 - Labour practices}

FBE achieved 1.78 score (see Table 1) FBE tries to recruit talents into its staff although not using any exactly defined talent management. FBE employs handicapped persons and flexibly reacts to their needs. These employees are provided with clearly suitable working conditions, some of them even exceeding the framework of legislative duties. FBE tries to keep maximum level of physical as well as mental wellbeing of its employees - provides theatre tickets, organises teambuilding activities, the staff as well as the students can visit the arboretum free of charge etc.

The persisting issues in this area substantially include crossfaculty communication and employee feedback, which is not provided at FBE at all.

\section{Key area KO-4 - The environment}

The lowest rating was obtained by FBE here (1.36 - see Table 1). FBE is engaged in this area in just basic activities such as waste sorting, paper and toner recycling, two-pole toilet flushing for water saving or purchase of recycled paper. However, FBE is as a rule not engaged in environment and ecosystem protection and renewal by its services and activities, taking no steps towards education of its staff on responsible use of natural resources and development of their environmental awareness and responsibility. The environmental criterion is only considered in public tenders in some and not all cases.

\section{Key area KO- 5 - Fair operating practices}

FBE was evaluated with the score of 2.06 (see Table 1). FBE clearly complies with all conditions of fair competition by all its activities, providing sufficient information about all courses and subjects available for study in the national and world languages. In the area of plagiarism, the university has a system in operation which is part of the university information system. However, there are no special programmes or bodies for corruption prevention, although the faculty has not detected any corruption case in its to-date history. FBE does not monitor its partners for cooperation with regard to their corporate social responsibility. And the CSR criterion is not included in public tenders.

\section{Key area KO-6 - Consumer issues}

The second highest rating was obtained by FBE in this key area (2.20 - see Table 1). FBE performs fair marketing, providing its stakeholders with particular, complete and unbiased information about its activities. Students are provided with "welfare" through student clubs and events, and an active Student Union. To support mental health of its students FBE provides psychological advisory service available at the ICV (Institute of Lifelong Learning). FBE also provides additional education to undergraduate and graduate students. Courses in excess of compulsory study subjects are available via ICV free of charge or discounted for students. FBE increasingly considers individual needs of students. Requirements of students with specific needs are found out by the study department before the course commencement by the student, in the context of the entrance examination and via ICV.

FBE also pays sufficient attention to interest group identification, trying to harmonise their interests with faculty interests. Student interests are mainly found out through evaluations. Information obtained in this way is discussed and considered by competent persons (pro-dean, teacher, guarantor etc.), who can react to them. Unfortunately, there is not feedback to feedback and so the students do not know whether and how their suggestions are addressed.

Insufficient activity has been detected in the sub-area of Sustainable Consumption. FBE is not explicitly engaged in resource wasting prevention and environment damage through consumer activities, does not keep statistics of annual resource saving and activities in the area of environment damage prevention. FBE also implements no systematic steps towards change of the present or future student behavioural patterns in the area of environment protection. FBE teaches subjects concerning CSR and ethics. However, these subjects are only compulsory for a single specialisation. For the other specialisations they are optional and thus not accessible to everybody.

\section{Key area KO-7 - Community involvement and development}

FBE achieved 1.83 score (see Table 1). Even though FBE has no special programmes for community engagement and no reserved funds for this area it still actively participates in educational and cultural community programmes. Some activities are implemented on the faculty level, others are organised by the Student Union, yet others on the university level and a few even only within the individual subjects taught.

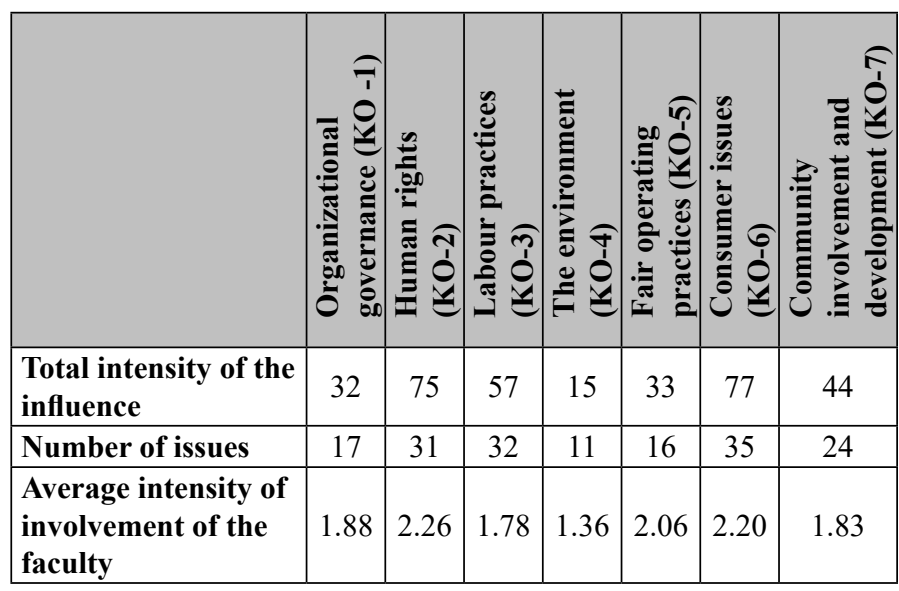

Table 1: Evaluation of the FBE MENDELU in Brno in key areas (source: own research) 


\section{Faculty of Business and Management (FBM), University of Technology Brno}

\section{Key area KO-1 - Organizational governance}

In the first key area (KO-1) FBM was rated 1.71 (see Table 2). CSR principles in the governance area are included in the ethical code of FBM and the Brno University of Technology as a whole. The ethical code is also a tool for ethical behaviour monitoring. It exists in the written format and is also published on the web site of FBM and university. FBM management considers responsible conduct an asset for the faculty and compliance with principles of ethics a significant part of the process of education, whether in the context of the courses or by following models in the surroundings. FBM evaluates ethical conduct of all academic staff, taking preventive measures and sanctions to prevent or in the case of violations. The faculty considers requirements of interest groups and takes measures to meet them and increase their satisfaction.

FBM does not have any established CSR strategy, though, no strategic documents where CSR would be included. FBM does not spread knowledge of socially responsible conduct among its stakeholders, employees are not involved in decision making about social responsibility issues. FBM is not member of any CSR platform, does not publish CSR reports, does not have social or ethical audits performed and has no body supervising corporate social responsibility compliance and ethical behaviour. CSR issues are only addressed by certain employees, either in their free time or in the context of their professional orientation.

\section{Key area KO-2 - Human Rights}

FBM score in second key area (KO-2) was 2.26 (see Table 2). FBM asserts human rights protection by its employees, students and interest groups. Compliance is monitored through a trust letterbox, a disciplinary committee, teaching evaluations and the academic senate.

FBM has so far met with no human rights violation within its walls. FBM has established procedures of action in risk situations. These procedures, however, follow from the university act, valid legislation of the Czech Republic, FBM and BUT statues and ethical codes.

FBM employs people without any discrimination, not monitoring their numbers and percentages, though. At present one third of managerial positions are held by women. This condition is not specifically monitored, though. Positions are also held by other ethnic and racial groups but this condition is not monitored either. Also students are admitted regardless their physical handicaps or race. Evaluation rules are clear and do not involve any discrimination. In the cases of collective bargaining there are trade unions as employee representatives. FBM respects the right of association, collective bargaining, exclusion of all forms of forced and child labour, but does not examine its suppliers from this point of view. Most FBM activities in this area are required by the law of the Czech Republic and are not in excess of compulsory legislative requirements.

\section{Key area KO-3 - Labour practices}

The second lowest rating was received by FBM in the third key area (KO-3), 1.66 (see Table 2). FBM performs human resource planning and applies defined procedures of HR management, based on organisational structure. The requirements are based on the needs of the individual institutes and a strategic council deals with this on the faculty level. However, FBM does not clearly plan human resources to prevent unnecessary limited period employments. Talent management is not established at FBM. FBM tries to keep physical, mental and social welfare of its staff and human resource development. Employees as well as students can use the Centre of Sports Activities (CESA) and training course of the Lifelong Education Institute.

FBM has no established outplacement. Overtime work is not extra paid. FBM has no authorised representative for social dialogue. Employment relationships are not monitored, various interest groups are formed and there is rivalry between institutes. Steps are taken in the context of labour relationship improvement but individually by single institutes and departments. FBM employees enjoy adequate working conditions, FBM takes care of their safety and health, but only within the scope of compulsory legislative requirements.

\section{Key area $\mathrm{KO}-4$ - The environment}

The lowest score of 1.18 (see Table 2) was achieved by FBM in key area $\mathrm{KO}-4$. In this area FBM is only engaged in waste recycling and purchase of energy-saving devices. No other activities in the area of environment protection are implemented, there is no environment protection budget and this criterion is not considered in public tenders either.

\section{Key area KO-5 - Fair operating practices}

FBM was evaluated with 2.00 score here (see Table 2). FBM complies with all defined conditions of fair competition by all its activities. FBM tries to provide sufficient information about the offered courses and subjects in Czech and in English. This information is shown on the faculty web site or in promotional materials. FBM conduct is transparent and all options are weighed before particular project selection. Subcontractors are not reviewed with regard to their corporate social responsibility and CSR criterion is not one of the criteria applied to public tenders. Other criteria are considered, which FBM deems not relevant, such as price, quality, lead times etc. FBM has no established anti-corruption programme but there has been no case of corruption among its staff so far. FBM does not publish CSR reports and its CSR activities on its web site. FBM respects ownership rights, especially copyright. Compliance is defined by law and the plagiarism control system is the tool.

\section{Key area KO-6 - Consumer issues}

The rating of FBM was 2.09 (see Table 2). FBM tries to harmonise interest of students with interest of the faculty. Information about student interests and needs is collected through teaching evaluations and information collection by the study department, and further through periodic questionnaire inquiries providing feedback for student service improvement. FBM monitors numbers of graduates, their success on the job market and graduate feedback at regular meetings. FBM also takes sufficient care of students in the OHS area. There is a faculty doctor available to them. FBM has introduced a new access system to the faculty premises and a new non-stop security guard service.

Social scholarships are provided to students from socially weak families. Students can also be granted bonuses for extraordinary achievement if the defined conditions are fulfilled. Additional education of undergraduates and graduates is provided through various courses, training sessions, certifications and optional subjects in cooperation with ICV. 
CSR-focused subjects taught at FBM include: Ethics in business, Corporate social responsibility and ethics in business, Social contact and rhetoric.

FBM uses fair marketing and there are special university-wide (BUT) regulations for marketing and publicity. There are, however, no emergency procedures to address issues in this area and there is no body supervising the marketing practices used.

\section{Key area KO-7 - Community involvement and development}

The last key area (KO-7) was scored for FBM with 1.75 (see Table 2). FBM engages in community involvement by some of its activities but without any comprehensive programme in this area. The activities include joint projects of faculties, conferences, cooperation with NGO and the private sector in the context of teaching. FBM is engaged in collection of PET bottle caps, chemist's and alimentary products and in support for the handicapped. FBM contributed to educational and cultural programmes within the community, for example by means of football and ice-hockey tournaments between universities, and offers Third Age University for seniors. However, in the context of investment decisions, purchases of products and services FBM does not consider new job opportunity creation and does not prefer local suppliers in public tendering processes. FBM does not make significant investments into infrastructure or other programmes for improvement of the social aspect of community life. Where the faculty does take part in these activities it is only singular and one-off actions that do not repeat and are not planned for this purpose.

\begin{tabular}{|c|c|c|c|c|c|c|c|}
\hline & 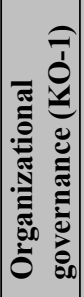 & 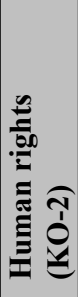 & 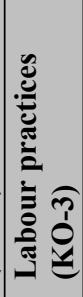 & 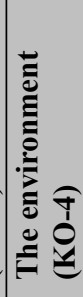 & 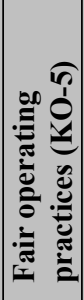 & 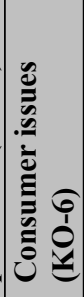 & 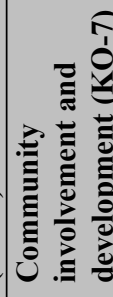 \\
\hline \begin{tabular}{|l|}
$\begin{array}{l}\text { Total intensity of the } \\
\text { influence }\end{array}$ \\
\end{tabular} & 29 & 70 & 53 & 13 & 32 & 73 & 42 \\
\hline Number of issues & 17 & 31 & 32 & 11 & 16 & 35 & 24 \\
\hline $\begin{array}{l}\text { Average intensity of } \\
\text { involvement of the } \\
\text { faculty }\end{array}$ & 1.71 & 2.26 & 1.66 & 1.18 & 2.00 & 2.09 & 1.75 \\
\hline
\end{tabular}

Table 2: Evaluation of the FBM University of Technology Brno in key areas (source: own research)

\section{Faculty of Economics and Administration (FEA), Masaryk University in Brno,}

\section{Key area KO-1 - Organizational governance}

The score of FEA in the first key area (KO-1) is high, 2.47 (see Table 3). FEA considers itself a public educational institution, co-creator of certain values and standards which should also become part of its existence. In this sense FEA tries to approach all its activities. A number of them originate on the university level. FEA as well as Masaryk University as a whole realize their social responsibility very well. That is also manifested by the governance method. The FEA management consider socially responsible conduct very beneficial. CSR strategy is formally included in the long-term plan of the faculty, based on the long-term plan of the university. On the university level there is a work committee of the senate focusing on CSR issues and bringing in new proposals based on suggestions of representatives of individual faculties. Also the material plan, submitted for approval to the academic senate together with the budget, defines material priorities, with a chapter on public relations, including socially responsible activities.

The long-term plan of FEA includes a specific strategic priority no 4 entitled Active Social Role. There FEA defines its strategic objectives in the area of social responsibility. FEA supports involvement of the whole faculty and its staff in socially responsible activities, creating an inspiring environment with the aim to support common value of the faculty and the subject, to create conditions of inclusion of disadvantaged students, to develop institutional partnerships with public and private sector institutions and to promote public discussion on society-wise themes connected with the professional profile of the faculty. FEA is also institutional member of the CSR involved parties platform. Principles of ethical behaviour are formally defined in the written ethical code of employees of Masaryk University in Brno. They mainly concern education, research, assessment and expert activities. The ethical code however also defines principles of teamwork, project planning, result publication, principles of collegial conduct, loyal relationship to the university and the public etc.

FEA considers requirements of stakeholders, as also follows from the faculty orientation and interest. FEA has developed a broad system of corporate partnerships. There are several FEA platforms established for the very reason of maintenance of contacts with other institutions and finding about their interests. FEA annually meets with its external partners to find about their requirements. FEA complies with the law of the Czech Republic, having all of its activities controlled by a lawyer. FEA implements no activity without legal assessment. However, FEA does not prepare CSR reports usable for periodic assessment and publication.

\section{Key area KO-2- Human Rights}

FEA score was 2.29 (see Table 3). FEA has so far addressed no human rights violation case, taking care of compliance with the law of the Czech Republic in this area. FEA carefully observes guidelines and standards of the faculty based on nondiscrimination principle. All FEA activities follow this principle although it is not formally defined. FEA employs people without any gender or nationality based discrimination. FEA does not monitor numbers of students and employees from other ethnic groups. There is a university-wide "Teiresiás" centre helping students with all sorts of handicaps successfully complete their studies.

\section{Key area KO-3 - Labour practices}

The key area KO-3 was scored with 2.22 (see Table3). FEA plans human resources, has defined procedures for human resource management. Employee recruitment is planned with the aim to prevent unnecessary temporary employments. However, FEA has not yet introduced any talent management practice. Employment relationships are considered very good and there are few cases of conflicts of interests of the faculty and its employees. FEA grants various awards to its academic staff, for example for the best professional book, for the best scientific article, Dean's prize for young scholars below 35 etc. Rector's prize is granted in categories like significant extraordinary result in international grant competitions, excellent teaching results, long-term excellent research results, active development of civic society etc. FEA employs handicapped employees. FEA takes 
care of further professional development of its staff. Long-term efforts in excess of compulsory legal requirements include the academic club on the premises of FEA. It is a multifunctional area accessible to all FEA employees, for example with a fully equipped kitchenette. Employees further receive a meal ticket contribution and can choose between meal tickets and subsidised school canteen meals. FEA provides many other employee benefits, such as vouchers for cultural and educational activities, organisation of tourist trips etc. Employees can take days off for overtime work.

Communication of FEA management with employees is assured through a periodic inquiry where FEA employees can express their opinions.

\section{Key area $\mathrm{KO}-4$ - The environment}

The lowest rating was received by FEA in this key area (KO4) -1.73 (see Table 3). FEA sorts waste and recycles plastics, paper and batteries. FEA tries to minimise document printing. FEA considers the environment in public tendering processes, with maximum effort at energy, water and material saving, for example by using saving water taps. FEA tries to be most sparing and economical in the area of water, soil and fuel management. FEA is member of a joint venture dealing in revitalisation of trees in the surroundings.

However, there is no official environmental guideline at FEA. There is no targeted course or project focused on change of employee attitude to the environment and their more environment-friendly behaviour at FEA. However, FEA tries to demonstrate model behaviour in this area and assumes the employee to follow its example in their everyday life.

\section{Key area KO-5 - Fair operating practices}

This key area (KO-5) was evaluated with 2.38 (see Table 3). FEA observes conditions of fair competition in all its activities, has simple and clearly defined rules in areas where fair governance might be violated, and respects ownership rights. FEA provides sufficient information about the offered courses and subjects in the national and world languages. The information is provided via standard communication channels - printed brochures, faculty web site, social networks. FEA is interested in corporate social responsibility of its potential partners and considers with aspect when selecting them. At the same time FEA promotes its social responsibility in its partners' organisations. In public tenders FEA considers the CSR criterion.

Although FEA does not create and publish any CSR report, CSR activities can be found on its web site.

\section{Key area KO-6 - Consumer issues}

In this key area (KO-6) the rating of FEA was the highest of all 2.57 (see Table 3). FEA operates a public relations and marketing department and has a pro-dean for public relations. Marketing is centralised at FEA, with clearly defined rules. In the healthcare area FEA pays sufficient attention to student requirements, trying to harmonise their requirements with faculty interests. Faculty students can use a gym and there is psychological advisory service available on the university level.

FEA takes care of student welfare through support for activities of student unions active at FEA. Foreign students can use a tutorial programme. Handicapped students are supported by the "Teiresiás" programme. FEA also organises activities focused on change of current values and behavioural patterns of students and employees. FEA tries to influence their responsible use of natural resources. In the context of social responsibility teaching there is a CSR subject taught at FEA in English. CSR is taught in the Czech language in the context of marketing courses. Communication aimed at finding out student interests is implemented through a periodic inquiry organised by the university. Employees are liable to work with the inquiries filled out by the students and respond to their comments and suggestions.

\section{This liability follows from the respective FEA guideline.}

The university offers its students to take optional subjects at any other faculty. To that end the timetable and schedule of the academic year are unified across the university so that the students can enrol for the optional subjects at other faculties as they like and successfully attend and pass them. FEA is involved in the project entitled "To work by bike", extended for its own purposes with "To school by bike".

FEA monitors numbers of successful graduates, their success on the job market and the time to their first job. FEA has established a data protection policy and programmes for support for students from socially weak families. The faculty further organizes various summer schools, foreign scholarships etc.

\section{Key area KO-7 - Community involvement and development}

The score of 2.33 (see Table 3) was obtained by FEA in this key area (KO-7). FEA cooperates with $\mathrm{NGO}$, the private sector, the city, the region, and the Economic Chamber. FEA is involved in many programmes for the community - such as financial literacy in cooperation with the City Foundation aimed at improvement of financial literacy of the youth. Under the auspices of the university the faculty has implemented a project called Juniversity including lectures for children at the age of $9-14$ years. FEA also joined the project of ESS entitled Living Together. The project focused in provision of accommodation for children leaving children's homes.

FEA is involved in community education programmes for all age categories, also thanks to the Third Age University. Many activities in this area are implemented in the context of lifelong education on the university level.

FEA does many things creating new job opportunities, which must make sense by themselves, not only as sources of job opportunities. The goal is not to provide money to people but to teach them to earn the money for their projects.

FEA tries to operate the faculty as an open place where people can meet.

Comparison of involvement of all three faculties in corporate social responsibility activities in the individual key areas pursuant to ISO 26000 standard is shown in Figure 1. 


\begin{tabular}{|c|c|c|c|c|c|c|c|}
\hline & 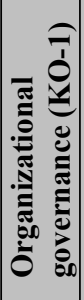 & 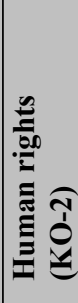 & 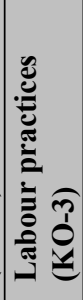 & 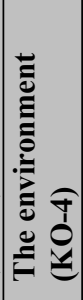 & 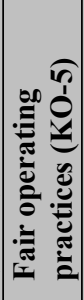 & 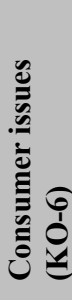 & 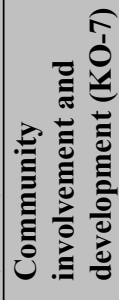 \\
\hline $\begin{array}{l}\text { Total intensity of the } \\
\text { influence }\end{array}$ & 42 & 71 & 71 & 19 & 38 & 90 & 56 \\
\hline Number of issues & 17 & 31 & 32 & 11 & 16 & 35 & 24 \\
\hline $\begin{array}{l}\text { Average intensity of } \\
\text { involvement of the } \\
\text { faculty }\end{array}$ & 2.47 & 2.29 & 2.22 & 1.73 & 2.38 & 2.57 & 2.33 \\
\hline
\end{tabular}

Table 3: Evaluation of the FEA Masaryk University in Brno in key areas (source: own research)

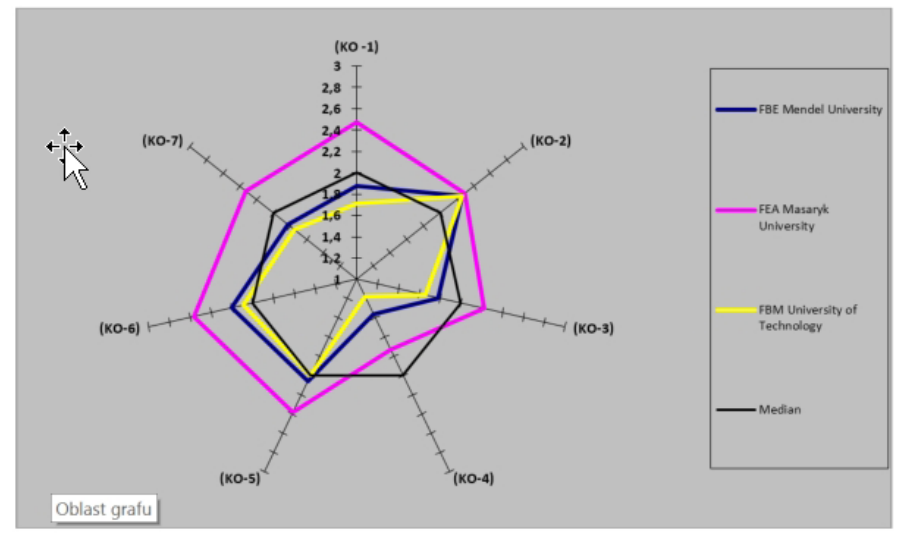

Figure 1: The average intensity of involvement of evaluated faculties in key areas (source: own research)

\section{Discussion}

Comparison of CSR survey results for individual faculties shows fundamental differences between FEA of Masaryk University and the other two faculties, FBM of University of Technology and FBE of Mendel University, in all assessed key areas except for KO-2 Human rights (see Figure 1). FEA exceeded the median value in all key aspects pursuant to ISO 26000 except for KO-4 Environment.

The main difference between the faculties lies in the fact that FEA has the CSR concept included in its strategy. It is the only faculty of the three analysed with a targeted corporate social responsibility approach and formulated CSR principles, with emphasis on socially responsible behaviour in all areas of its activity. Corporate social responsibility is part of long-term orientation of both Masaryk University and FEA. Faculty management considers CSR beneficial for the faculty, there is a working committee for CSR on the university level and the CSR concept is part of the material plan of the university. Neither of the other two assessed faculties has the CSR concept CSR built into their activities in any similar way.

All three faculties received above-average scores in key area KO-2 Human rights, FEA 2.29, FBM and FBE 2.26. This was despite the fact that most activities implemented by the faculties in this key area KO-2 only meet compulsory legislative requirements with minimum engagement in excess of the legislative requirements. Although Kuldová (2012) states that organisations should also take steps beyond the compulsory legislative scope to voluntarily apply principles of the three pillars of social responsibility - the economic, the social and the environmental - for their activities to be considered really socially responsible. To tell the truth, the ISO 26000 standard, used as the basis for the evaluation, much corresponds in the key area KO-2 with legislative requirements of the Czech Republic, and as all evaluated faculties comply with valid Czech legislation, their rating in this area was very high despite the fact that they hardly step beyond their legislatively defined obligations.

The key area KO-4 Environment proved to be problematic for all analysed faculties. All three scorings were below the median value of 2. FEA was scored with 1.73, FBE with 1.36 and FBM with 1.18. Environment area is on a rather low level at each of the three faculties. All of them are only engaged in waste recycling, energy saving and other natural resource sparing. The environmental criterion is only considered in the context of public tendering by FEA. The faculties do not take any further steps towards specific activities in this area. And yet the role of the environment and its protection is prioritised now and the stakeholders are interested in how the organisation they are related to addresses the environmental issues. This is confirmed for example by Flammer (2013), who says that shareholders are sensitive to corporations' environmental footprint and they react positively to the announcement of eco-friendly initiatives.

In all other key areas, namely KO-3, KO-5, KO-6, and $\mathrm{KO}-7$, FEA was always above the median level 2 and the other two faculties FBM and FBE either tightly reached the median value of 2 or were below it.

In KO-3 Labour practices the main difference between FEA and FBM, FBE was in communication with employees and overall benefits in excess of legislative requirements (working hours of academic staff and academic club). FEA emphasizes employee satisfaction and good labour relationships.

In the key area KO-5 Fair operating practices FEA, again rated higher than the other two faculties, in addition examines and promotes corporate social responsibility in relation to its partners. The faculty does not partner with anybody and chooses socially responsible partners. In addition, the CSR criterion is considered in the context of public tenders.

In the key area KO-6 Consumer issues the main difference between FEA and FBM and FBE was in communication with students and feedback provision to their comments and suggestions considered by FEA as very important. In addition, FEA has the "Teresiás" organisation for work with and assistance to handicapped students.

FEA achieved a significantly better score in the last key area KO-7 Community involvement and development again when compared to the other two faculties, FBN and FBE. Its engagement focused on the community is again far above the other two, with the highest number of community-focused programmes. Also its approach to community education - not straightforward subsidy provision but teaching how to earn the needed money - may be a good example to follow by others.

The results therefore confirm the basic assumption that corporate social responsibility should be built into strategic management of universities without which CSR development at the university cannot be sufficient. Analyzed HEIs in the Czech 
Republic perform many socially responsible activities but not always in the targeted manner and often as by-products of other activities. This is the first thing to be changed. CSR activities at HEIs must be strategically planned and organized, promoted to partners, employees, students and other stakeholders. HEIs should take corporate social responsibility as one of their strategic goals, include it into their long-term orientations and other strategic documents and have their activities governed by that. Hahn (2013) emphasizes the need for CSR planning and strategic building into organisation activities with awareness of what is not appropriate and ethical. At the same time, however, he points out that building social and environmental aspects into corporate strategies is not easy and requires willingness and readiness to accept CSR as one of the corporate values. In addition, social responsibility of conduct is perceived with great sensitivity by the surrounding stakeholders and the society. And where the HEI itself behaves with social responsibility in mind, it can serve as an example to follow by others. Important aspects of this activity also include CSR activity reporting and communication. The annual report on CSR, information about CSR in annual reports, on corporate web sites and in social networks should go without saying. Support in this key area may come from the existing CSR platforms which HEIs can become members of.

Another important proposal for improvement is enhanced communication with all stakeholders both in the key area KO 3 - Labour practices and in KO-5 Fair operating practices as well as KO-6 Consumer issues. The need for and role of communication with and between employees, students, partners and other stakeholders is crucial. Every stakeholder my contribute specific suggestions which may significantly shape the development and face of CSR and elsewhere. Where sufficient room for communication is not provided the status quo cannot be improved. If HEIs learn to consider all stakeholders including the community and listen to their needs they can create really socially responsible environment together.

The third suggestion for change is focused on targeted effect on long-term sustainable consumption both in the key area $\mathrm{KO}-4$ environment and in KO-6 Customer issues as well as KO-7 Community involvement and development. University as an educational institution can affect conduct of its students, employees and the community as a whole. Hence the importance of targeted teaching focused on corporate social responsibility and environment protection not only for undergraduate students but also in the form of specific educational and other community focused activities.

Like in the profit sector in the area of tertiary education too social responsibility may help HEIs improve their image, public relations, increase employee loyalty and attract talented students and high-standard employees.

Limitations of the performed research mainly lie in the recommending and self-evaluating nature of the ISO 26000 standard, involving the element of individual perception and evaluation by the project team and individual respondent setting. The differences between the analysed faculties might in some case be also affected by this aspect.

Focus of further research on more different areas might be beneficial. The research sample of the assessed schools should in future be extended by other public and private universities of the Czech Republic and other countries. Further research might also try to find out whether there are differences between actual and declared CSR activities in the tertiary education sector. Othman and Othman (2014) states that CSR is often seen by critics as little more than a public relations exercise designed to give the appearance of social responsibility while in reality doing nothing to change corporate priorities or operating practices. Also the effects of inclusion of the CSR concept in HEIs on their performance and other aspects of their activities have not been sufficiently described yet.

\section{Conclusion}

The presented research results are a part of the complex research of the CSR in the tertiary sector. The case of faculties of economics at public universities in the Czech Republic shows that corporate social responsibility does exist in the tertiary education sector in the Czech Republic and develops too but is not yet always implemented in a targeted manner in the school strategies, appropriately communicated and reported. That is also one of the main drawbacks of the assessed faculties. The main output of the research is the finding that the HEIs with the CSR concept built in their strategic documents are more widely engaged in most of the key areas evaluated pursuant to ISO 26000. This also confirms the above assumption that corporate social responsibility should be built into strategic management of universities without which CSR development at the university cannot be sufficient. This fact is clearly demonstrated by the evaluation results of FEA of Masaryk University in Brno. Social responsibility may only be pursued and implemented in organisation activities well on condition of the organisation management's favourable and understanding approach to the need of its development.

\section{Acknowledgement}

This article was supported by the Norway Grants under Grant "Institutional Cooperation in Responsible and Sustainable Education" with Hedmark University College, number CZ07.

\section{References}

Ahmad, J. (2012) 'Can a university act as a corporate social responsibility (CSR) driver? An

Analysis', Social Responsibility Journal, Vol. 8, No. 1, pp. 7786. DOI: $10.1108 / 17471111211196584$.

Aya Pastrana, N., Sriramesh, K. (2014) 'Corporate Social Responsibility: Perceptions and practices among SMEs in Colombia', Public Relations Review, Vol.40, No. 1, pp. 14-24. DOI: 10.1016/j.pubrev.2013.10.002.

Černohorská, L., Putnová, A. (2012) Společenská odpovědnost firem a jak ji měrit?. 1. ed. Brno: Akademické nakladatelství CERM. 130 p.

Formánková, S., Kučerová, R., Prísažná, M. (2016) 'ISO 26000: Concept of Social Responsibility at Czech University', Proceedings of the 6th International Conference on Management (ICOM 2016), Brno, [in press].

Flammer, C. (2013) 'Corporate Social Responsibility and Shareholder Reaction: The Environmental Awareness of Investors', Academy of Management Journal, Vol. 56, No. 3, pp. 758-781. DOI: 10.5465/amj.2011.0744.

Giacalone, R. A., Thompson, K. R. (2006) 'Business Ethics and Social Responsibility Education: Shifting the Worldview', Academy of Management Learning \& Education, Vol. 5, No. 3, pp. 266-277. DOI: 10.5465/AMLE.2006.22697016.

Hahn, R. (2013) 'ISO 26000 and the Standardization of Strategic Management Processes for Sustainability and Corporate Social 
Responsibility', Business Strategy \& The Environment (John Wiley \& Sons, Inc), Vol. 22, No. 7, pp. 442-455. DOI: 10.1002/ bse. 1751.

ISO. (2013) 'ISO 26000 - Social responsibility', [Online], Available: http://www.iso.org/iso/iso26000[10 Dec 2015].

ISO. (2013) 'Schematic overview of ISO 26000', [Online], Available: http://www.iso.org/iso/sr_schematic-overview.pdf [11 Dec 2015].

Jorge, M. L., Peña, F. A. (2014) 'Determinants of corporate social responsibility and business ethics education in Spanish universities', Business Ethics: A European Review, Vol. 23, No. 2, pp. 139-153. DOI: 10.1111/beer.12041.

Kuldová, L. (2012) Nový pohled na společenskou odpovědnost firem: strategická CSR. 1. ed. Plzeň: Nava. 176 p.

Lehmann, M., Christensen, P., Thrane, M., Jørgensen, T. H. (2009). 'University engagement and regional sustainability initiatives: some Danish experiences', Journal of Cleaner Production, Vol. 17, No. 12, pp. 1067-1074. DOI: 10.1016/j. jclepro.2009.03.013.

Madzík, P. et al. (2015). Dobrá prax v oblasti spoločenskej zodpovednosti $v$ prostredi vzdelávacej inštitúcie. 1.ed. Ružomberok: Verbum.

Milton de Sousa Filho, J., Wanderley L. S. O., Gómez, C. P., Farache, F. (2010) 'Strategic Corporate Social Responsibility Management for Competitive Advantage', BAR: Brazilian Administration Review, Vol. 7, No. 3, pp. 294 -310.

Moratis, L. (2014) 'ISO 26000', Journal of Corporate Citizenship, No.53, pp. 77-90.

Othman, R., Othman, R. (2014) 'Higher education institutions and social performance: evidence from public and private universities', International Journal of Business \& Society, Vol. 15, No. 1, pp.1-18.

Stojanová, H., Tomšík, P. (2014) 'Factors influencing employment for tertiary education

graduates at the selected universities', Agricultural Economics, Vol. 60, No.8, pp. 376-387

Ubius, U., Alas, R. (2012) 'The Impact of Corporate Social Responsibility on the Innovation Climate', Engineering Economics, Vol. 23, No. 3, pp. 310-318. DOI: http://dx.doi. org/10.5755/j01.ee.23.3.1935.

Vazquez, J. L., Lanero, A., and Licandro, O. (2013) 'Corporate Social Responsibility and Higher Education: Uruguay University Students' Perceptions', Economics and Sociology, Vol. 6, No.2, pp. 145-157. DOI: 10.14254/2071-789X.2013/6-2/13.

Yokoyama, K. (2006). 'Entrepreneurialism in Japanese and UK Universities: Governance, Management, Leadership, and Funding', Higher Education, Vol. 52, No. 3, pp. 523-555. DOI: 10.1007/s10734-005-1168-2.

Yusoff, H., Mohamad, S., Darus, F. (2013) 'The Influence of CSR Disclosure Structure on Corporate Financial Performance: Evidence from Stakeholders' Perspectives', Procedia Economics \& Finance. Vol. 7, pp. 213-220. DOI: 10.1016/ S2212-5671(13)00237-2. 